\title{
Prediction of Flow Distribution for Bingham Fluid in a Slot Die
}

\author{
Masayuki NAgASHIMA*, Tomiichi HASEGAWA $^{* *}$, and Takatsune NARUMI ${ }^{* *}$ \\ "Dai Nippon Printing Co., Ltd. \\ 1-3, Midorigahara, 1-chome, Tsukuba-shi, Ibaraki 300-2646, Japan \\ ${ }^{* *}$ Faculty of Engineering, Niigata University \\ 8050, 2-no-cho, Ikarashi, Niigata 950-2181, Japan
}

\begin{abstract}
Designs of flow channel in a slot die are often required to achieve the uniform thickness of coated films for nonNewtonian fluids having nonnegligible yield stress. In previous studies we have proposed a designing method for deriving the optimum geometries of flow channel from a flow distribution model for Bingham fluid. However, it is hard to provide the optimum geometries precisely without manufacturing burden. Therefore, it is useful to substitute simplified asymptotic curves for complex optimum geometries in designing flow channel. But in that case the deviation of outflow from uniformity due to such approximations needs to be checked whether it is within an allowable range or not. In this work we propose a method for predicting the outflow deviation in given geometories of flow channel using Bingham fluid. The usefulness of the method is confirmed by an experiment conducted using a corresponding fluid.
\end{abstract}

Key Words: Bingham fluid / Yield stress / Flow behavior / Algebraic analysis

\section{押出し金型におけるビンガム流体の流量分配予測}

長島 正幸*, 長谷川 富市**, 鳴海 敬倫 ${ }^{* *}$

(原稿受理:2006年2月 20日)

1. 緒言

均一な厚さの塗布膜を得るのに適した押出し金型塗布方 式は，塗布液が外気にほとんど触れず，ロスが極めて少ない 等の特長も併せ持つことから, 材料が敏感で高価なエレクト ロニクス分野や産業資材分野等のさまざまな分野で利用さ れている.

押出し金型は塗布の幅方向に液を分配する分配室と, 分配 された液を平行に吐出して基材に連続的に塗布膜を供給す るスリットから成る内部流路を持つ. 均一な厚さの塗布膜を 得るにはスリットからの吐出偏差がないことが重要となる.

押出し金型塗布において, 感材に代表されるニュートン流 体を使用する場合は, 分配室の断面やスリットの間隙が一定 な単純形状でも偏差の少ない吐出が得られることが知られ ている. しかし, 近年使われるようになってきた磁性材料や 誘電性マイクロカプセル等の多様な粒子が分散された塗布 液には, 顕著な非ニュートン性を持つものが多く, ${ }^{1-3)}$ ダイラ タント性を持つような特殊な場合を除いて, ${ }^{4)}$ 大きな吐出偏差 を生じさせる. ${ }^{5-7)}$

このような流体に対する吐出偏差の抑制手段としては，特 別な内部流路形状を持たせた金型の使用が有効である. ${ }^{8,9)}$ 内 部流路の設計にあたっては, 有限要素法, 有限体積法等の3

*大日本印刷株式会社 † 300-2646 つくば市緑ヶ原 1-1-3

** 新潟大学工学部機械システム工学科 $\overline{9} 950-2181$ 新潟市五十嵐 2 の町 8050
次元数值解析シミュレーションを用いた試行錯誤法という 手段もあるが, ${ }^{9-12)}$ 内部流路の非常に大きなアスペクト比 $\left(10^{3} \sim 10^{4}\right)$ による計算の時間的な負荷がかなり大きいことか ら, 設計者たちは内部流動を効率的に評価するモデルの研究 を行ってきた.例えば, Weinstein, Tsudaらは代表的な非ニュー トン的性質であるシェア・シニング性に注目したさまざまな 流体モデルを用い, 独自の手法で導き出した効率的で精度の 良い内部流路設計手法を提案している. 13-17)

著者らは前報において，低速での押出し金型塗布に関して 降伏応力の存在のために吐出偏差が発生しやすいビンガム流 体を対象として, 吐出偏差を解消できる理想的な内部流路の 形状を, 精度良くかつ効率的に導出できる手法を提案した. ${ }^{18)}$

しかし, 導出された理想的な内部形状は，一般的には単純 な関数で表現することのできない複雑な曲線である. NCフラ イス盤や成型砥石の使用により，この形状を加工することは 可能であるが，そのコストは非常に高くなる.

この対策として，算出された理想的な内部形状を比較的加 工の容易な直線や単純な曲線で近似して, 金型を加工する方 法が有効である。しかし，理想的な形状からのずれが流量分 配にも影響を及ぼし，吐出偏差を生じることとなる．金型の 内部流路設計においては，この吐出偏差が製品が所望する許 容範囲内に収まる必要がある.

本報においてはこの吐出偏差の評価を目的として, ビンガ ム流体に対する前報の結果を応用して，任意のスリット形状 における吐出偏差を予測する手法を提案する。 その一例とし 
て, 金型の形状加工時の加工負荷を軽減すべく, スリット形 状（スリット間隙）を理想的な曲線形状に対して擬似的に直 線形状で加工した押出し金型を用いた場合の吐出偏差の予測 結果を紹介する，また本手法について，計算結果と実験值の 比較を行い, 内部流路流動解析における有効性を確認する.

\section{2. 主な記号}

$B: x^{*}=1$ におけるスリット形状(スリット間隙の $1 / 2$ )

$B\left(x^{*}\right)$ : 任意の位置 $x^{*}$ におけるスリット形状

${ }_{B}^{k}\left(x^{k}\right): k$ 番目の金型ブロックにおける理想化されたスリッ 卜形状

$B_{\mathrm{AP}}\left(x^{*}\right)$ : 理想的スリット形状を直線で近似したスリット形状

$L: x^{*}=1$ におけるスリット長

$N_{\mathrm{B}}:$ ビンガム数 $=\tau_{0} R /\left(\mu_{0} \bar{v}_{0}\right)$

$p\left(x^{*}\right)$ : 分配室内圧力

$p^{*}\left(x^{*}\right)$ : 分配室内無次元圧力 (圧力/粘性応力)

$p^{k}\left(x^{k}\right): k$ 番目の金型ブロックにおける分配室内無次元圧力

$q_{\mathrm{z}}\left(x^{*}\right)$ : スリット単位塗布幅あたり流量（スリット流量）

$q_{z}^{*}\left(x^{*}\right):$ スリット規格化流量

$\left.q_{z}{ }^{*}{ }^{k} x^{*}\right): k$ 番目の金型ブロックにおけるスリット規格化流量

$\frac{k}{q_{z}^{*}}: k$ 番目の金型ブロックにおける平均スリット規格化 流量

$Q_{0}: x^{*}=0$ における分配室流量 $=$ 投入流量

$Q_{\mathrm{x}}\left(x^{*}\right)$ : 分配室流量

$Q_{x}^{*}\left(x^{*}\right)$ : 分配室規格化流量

${\stackrel{h}{Q^{*}}}^{*}\left(x^{*}\right): k$ 番目の金型ブロックにおける分配室規格化流量

$R:$ 分配室断面半径

$\bar{v}_{0}: x^{*}=0$ における分配室内平均流速

$W:$ 分配室奥行き長さ

$\mu_{0}:$ 流体の塑性粘度

$\tau_{0}:$ 流体の降伏応力

* : 無次元数記号

\section{3. 解析モデル}

本章では，押出し金型の内部流動の解析モデルについて説 明する. 3.1 項のモデルの設定と 3.2 項の基礎流量方程式の導 出に関しては, 著者らが以前に行った報告 ${ }^{18)}$ で示したモデル および手法と共通するものであるため, 本報告内容を理解す る上で最低限必要と思われる事項（座標や変数の定義等）に ついてのみ記す.

\section{1 押出し金型の内部流動モデルの基本設定}

Fig.1 に金型内部の流路モデル図を示す. 金型の内部流路 は, 塗布幅の方向 ( $x$ 軸で表す) に液を輸送する分配室と, 分 配された液を金型外部に押出す方向（ $z$ 軸で表す）に輸送する スリットから成る。

分配室は一定半径 $R$ の真円の断面を持つ真円筒であるが, スリットは平板状であるので, 分配室とスリットで異なる座 標系を採用する。

分配室には, 円筒座標系 $(r, \theta, x)$ を採用し, 入口を $x=0$, 終端を $x=W(=$ 奥行き長さ=塗布幅 $)$ とする. また, $x$, $r$ の規格化座標を $x^{*}=x / W, r^{*}=r / R$ で与える.

スリットには, 分配室と $x$ 座標を共通とする直線直交座標
系 $(x, y, z)$ を採用する. $y$ 軸はスリット間隙の中心面の座標 がゼロとなるようにスリット間隙方向にとり， $z$ 軸は分配室 側面に直結するスリット入口の座標がゼロとなるようにス リット長さ方向にとる.

スリットの底面から上面までの距離をスリット間隙 $2 B(x)$ として与え，スリット入口から出口までの距離をスリット長 $L(x)$ として与える. ただし, これらの変化の勾配は小さい(そ れぞれ $0.1 \%, 1 \%$ 以下). スリット閒隙，スリット長ともに $x$ の夕の関数で, $x=W\left(x^{*}=1\right)$ において，それぞれ $2 B, L$ の值を とるものとする．また， $\mathrm{y}, \mathrm{z} の$ 規格化座標を $y^{*}=y / B, z^{*}=z / L$ で与える.

ここでは内部流路形状の決定に必要な $W, R, L, B$ を, 流 路設定条件と呼ぶ.

非圧縮性流体の等温定常状態における運動方程式および 連続の式は，分配室およびスリットでのそれぞれの座標系に おいて，ともに式(1)，(2)のように表される．ただし，ここで は降伏応力と粘性応力が支配的な粘塑性体の流動を取り扱 うため, 流路内における慣性力の影響, 体積力の影響は無視 できる19)ものとする.

$$
\begin{aligned}
& -\nabla p+\nabla \cdot \boldsymbol{\tau}=\mathbf{0} \\
& \nabla \cdot \boldsymbol{v}=0
\end{aligned}
$$

\section{2 金型内部の流れの支配方程式と定式化}

\subsection{1 分配室内の流れ}

ここで，分配室においてはスリット方向の流れの影響を無 視し, $x$ 方向のみの流れとする.この仮定は, 一般の押出し金 型のアスペクト比が充分に大きいことから妥当であり, 本研 究で扱うビンガム流体モデルに対して適用可能であること がWeinsteinやKamişliらによって示されている. ${ }^{14,16)}$ 本仮定は power-law流体モデルをはじめとするいくつかの流体モデル を使用した押出し金型内部の流動解析に適用できることがす でに示されており，一般的にも幅広く用いられている.4,7,13-17)

液にかかる応力 $\tau_{r x}$ に関しては, ずり流動におけるビンガム 流体モデルを適用し，規格化座標を用いてまとめると，分配 室内の流れは式(1), (2)より，次式(3)のように表される。

$$
-\frac{1}{W} \frac{d p}{d x *}=\frac{1}{R r^{*}} \frac{d}{d r^{*}}\left(r *\left(-\frac{\mu_{0}}{R} \frac{d v_{x}}{d r^{*}}+\tau_{0}\right)\right)
$$

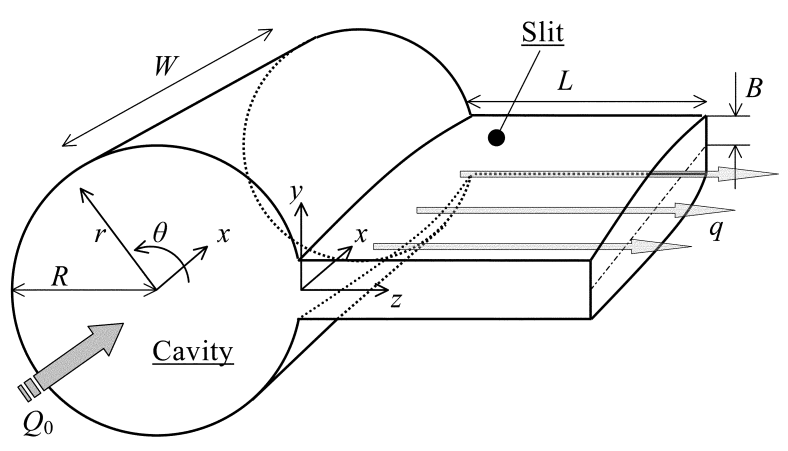

Fig. 1. Geometry of cavity die. 
分配室壁面において，液の流速をゼロと仮定して，これを 分配室内流速 $v_{x}$ について解く. そして, この流速を $x$ 方向の分 配室断面で $r$ おび $\theta$ 方向に積分すると分配室内の流量 $Q_{x}\left(x^{*}\right)$ が得られる。

この $Q_{x}\left(x^{*}\right)$ を $x^{*}=0$ における流量 $Q_{0}=\pi R^{2} \bar{v}_{0}$ (投入流量) で規 格化すれば, 分配室規格化流量 $Q_{x}^{*}\left(x^{*}\right)$ が次式(4)で表される. ただし, $N_{\mathrm{B}}, p^{*}\left(x^{*}\right)$ は以下のように定義されているものとする.

$$
Q_{x}^{*}\left(x^{*}\right)=-\frac{1}{8} \frac{R}{W} p^{* \prime}\left(x^{*}\right)-\frac{1}{3} N_{\mathrm{B}}-\frac{2}{3} N_{\mathrm{B}}^{4}\left(\frac{R}{W} p^{* \prime}\left(x^{*}\right)\right)^{-3}
$$

$$
\begin{aligned}
& N_{\mathrm{B}}=\frac{\tau_{0} R}{\mu_{0} \bar{v}_{0}} \\
& p^{*}\left(x^{*}\right)=\frac{R}{\mu_{0} \bar{v}_{0}} p\left(x^{*}\right)
\end{aligned}
$$

$N_{\mathrm{B}}$ は分配室内の降伏応力と粘性応力の比を示す無次元数 でビンガム数 ${ }^{20)}$ と呼ばれる. $p^{*}\left(x^{*}\right)$ は分配室内圧力 $p\left(x^{*}\right)$ と粘性 忘力の比を示す無次元数である. $\bar{v}_{0}$ は分配室入口 $\left(x^{*}=0\right)$ にお ける平均流速である.

$Q_{x}^{*}\left(x^{*}\right)$ は $0 \leq Q_{x}^{*}\left(x^{*}\right) \leq 1$ の值をとり, 分配室入口 $\left(x^{*}=0\right)$ におい て1, 分配室終端 $\left(x^{*}=1\right)$ においてはゼロとなる.

\subsection{2 スリット内の流れ}

スリット流れに関して, $z$ 方向に対し $x$ 方向の圧力勾配は 充分に小さく, 流れは $z$ 方向にのみ存在すると仮定する. ${ }^{14,16)}$ 液にかかる応力 $\tau_{y z}$ に関して分配室と同様, ずり流動における ビンガム流体モデルを適用し, 座標を規格化してまとめる と, スリット内の流れは式(1), (2)より次式(7)のように表さ れる。

$$
-\frac{1}{L} \frac{d p}{d z^{*}}=\frac{1}{B} \frac{d}{d y^{*}}\left(-\frac{\mu_{0}}{B} \frac{d v_{z}}{d y^{*}}+\tau_{0}\right)
$$

スリット壁面において，液の流速をゼロと仮定して，これ をスリット流速 $v_{z}$ について解く. そして, この流速を $y$ 方向に 積分することで，スリットの単位塗布幅あたりの流量（以下 スリット流量) $q_{\mathrm{z}}\left(x^{*}\right)$ が得られる.

このとき, スリット入口での圧力 $\left.p\right|_{z^{*}=0}$ は共通座標 $x$ におけ る分配室内圧力 $p\left(x^{*}\right)$ と等しいものとし, スリット出口の圧力 $\left.p\right|_{z^{*}=1}$ は大気圧 $(=0)$ とすると, スリット内の圧力勾配 $d p / d z^{*}$ は $p\left(x^{*}\right) /\left(L\left(x^{*}\right) / L\right)$ となる.

これをスリット流量 $q_{z}\left(x^{*}\right)$ を表す式に代入し, 平均スリット 流量 $\bar{q}_{\mathrm{z}}=\pi R^{2} \bar{v}_{0} / W$ で規格化すると, スリット規格化流量 $q_{z}^{*}\left(x^{*}\right)$ は 次式(8)で表される.

$$
\begin{aligned}
& q_{z}^{*}\left(x^{*}\right)=\frac{1}{3} \frac{B\left(x^{*}\right)^{3} W}{\pi L\left(x^{*}\right) R^{3}} \\
& \left(2 p^{*}\left(x^{*}\right)-3\left(\frac{L\left(x^{*}\right)}{B\left(x^{*}\right)} N_{\mathrm{B}}\right)+\left(\frac{L\left(x^{*}\right)}{B\left(x^{*}\right)} N_{\mathrm{B}}\right)^{3} p^{*}\left(x^{*}\right)^{-2}\right)
\end{aligned}
$$

ここで, $q_{z}^{*}\left(x^{*}\right)$ は各位置 $x^{*}$ におけるスリット流量の偏差を表
すパラメータで, $q_{z}^{*}\left(x^{*}\right)-1$ を吐出偏差と呼ぶ。 吐出偏差のな い（偏差 $=0 ）$, 理想的な押出し金型塗布においては $x^{*} の$ 全域 $\left(0 \leq x^{*} \leq 1\right)$ において $q_{z}^{*}\left(x^{*}\right)=1$ が成立する.

また, $q_{z}^{*}\left(x^{*}\right)$ と $Q_{x}^{*}\left(x^{*}\right)$ の間には常に以下の関係が成立する.

$q_{z}^{*}\left(x^{*}\right)=-\frac{d Q_{x} *\left(x^{*}\right)}{d x^{*}}$

\section{3 理想的な押出し金型形状の持つ問題点とその対策}

本報においても前報と同様に，スリット形状を決定する $L\left(x^{*}\right), B\left(x^{*}\right)$ のうち $B\left(x^{*}\right)$ のみを変化させる $\left(L\left(x^{*}\right)=L\right.$ :一定 $)$ 場 合を考える.

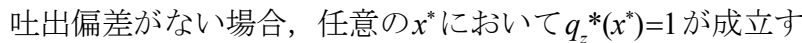
る. また， $x^{*}=1$ において $B\left(x^{*}\right)=B$, すべての $x^{*}$ において $L\left(x^{*}\right)=L$ が成立する，これら条件と式(4)，(8)，(9)を連立させて $B\left(x^{*}\right)$ について解く。これにより得られる理想的なスリット形状 $B\left(x^{*}\right)$ の導出の詳細については前報にて報告済みであるが，相 当複雑な曲線となる. ${ }^{18)}$

$\mathrm{NC}$ フライス盤や成型砥石の使用により上記の形状を加工 することは可能であるが，特に高い加工精度を求められる押 出し金型の加工においては，直線的な加工に比べてそのコス 卜は非常に高くなるという問題があった。このような金型加 工上の負荷を軽減すべく，算出された理想的な形状を比較的 加工の容易な直線等の単純な関数で分割近似して加工する 方法が有効である。しかし，理想的な形状からの形状のずれ が流量分配にも影響を及ぼし，吐出偏差を生じることとな る. 金型の内部流路設計においては，この吐出偏差が製品の 所望する許容の範囲内に収まる必要がある.

そこで，本報においてはこの吐出偏差の評価を目的とし て，ビンガム流体に対する前報の結果を応用して，任意のス リット形状における吐出偏差を予測する手法を提案すると ともに，本手法を用いたスリット形状の近似の例について紹 介する，本手法を用いれば，近似された形状に限らず任意の スリット形状を持つ押出し金型において，塗布液の物性や塗 布速度等の条件が変更された場合においても吐出偏差の予 測が可能であり，これについても例示する.

\section{4 任意のスリット形状における吐出偏差の予測}

\subsection{1 内部流路分割モデルの設定}

任意のスリット形状に対する流量分配を求めるには，式 (4), (8), (9)を連立して非線形の微分方程式を解く必要があ る.しかし，これには相当の困難を伴うため，前報18)で述べ た理想的なスリット形状の算出法を利用することで，簡便に 精度良く流量分配を予測する新たな手法を提案する。

ここで，スリット形状 $B\left(x^{*}\right)$ が任意に与えられているものと する.ただし， $B\left(x^{*}\right)$ は $x^{*}$ に対して単調増加する関数であるも のとする. 分配室内圧力は $x^{*}$ の増加に伴い吐出と摩擦により 減少するため，スリット間隙 $\left(=2 B\left(x^{*}\right)\right)$ を狭くしていくこと は吐出をできるだけ均一にしたいという目的に反すること になる。

Fig.2のように内部流路を $x$ 方向に $N$ 個のブロックに等分割 し，それぞれを微小幅 $(W / N)$ を持つ押出し金型ブロックと 見なす，そして,$k$ 番目の金型ブロックにつき，新たに規格化 座標 $x^{*}$ を与える. 
このとき，以下の関係が成立する.

$$
x^{*}=\frac{k-1+x^{*}}{N} \quad\left(0 \leq x^{*} \leq 1\right)
$$

ここで, $k$ 番目の金型ブロックにおける分配室内圧力, 分 配室流量およびスリット流量をそれぞれ ${ }_{p}^{k}\left(x^{*}\right), \stackrel{k}{Q}_{x}\left(x^{k}\right),{ }_{q}^{k}\left(x^{k}\right)$ とする. このとき, $k$ 番目の金型ブロックにおける分配室流量 の減少分がスリット流量に等しいことから, 次の関係が成立 する.

$$
\frac{d \stackrel{k}{Q_{x}\left(x^{*}\right)}}{d x^{*}}=-q_{z}\left(x^{*}\right) \frac{W}{N}
$$

また，各金型ブロック間における連続性から，以下の関係 が成立する。

$$
\begin{aligned}
& \stackrel{1}{p}(0)=p(0), \quad \stackrel{N}{p}(\stackrel{N}{1})=p(1), \\
& p(0)=p^{k}(1) \quad(1 \leq k \leq N-1) \\
& \stackrel{1}{Q_{x}}(\stackrel{1}{0})=Q_{0}, \quad \stackrel{N}{Q_{x}}(\stackrel{N}{1})=0, \\
& Q_{x}^{k+1}(0)=Q_{x}^{k+1}(1) \quad(1 \leq k \leq N-1)
\end{aligned}
$$

ここで, $k$ 番目の金型ブロックのスリット形状を，スリッ 卜流量 ${ }_{z}^{k}\left(x^{k *}\right)$ がブロック内の平均スリット流量 $\frac{k}{q_{z}}$ で一定とな るように各ブロック毎に理想化されたスリット形状 $B_{\mathrm{c}}^{k}\left(x^{k}\right)$ で 近似する.ただし, 各ブロックの分配室終端部では本来与え られたスリット形状 $B\left(x^{*}\right)$ に等しい $\left(B_{c}^{k}(1)=B(k / N)\right)$ ものとす る. (Fig.3参照)

このとき, 式(11)を積分する $\left.{ }_{x}^{k}{ }_{x}^{k} x^{*}\right)$ と $\frac{k}{q_{z}}$ との間に以下の関係 が成立する。

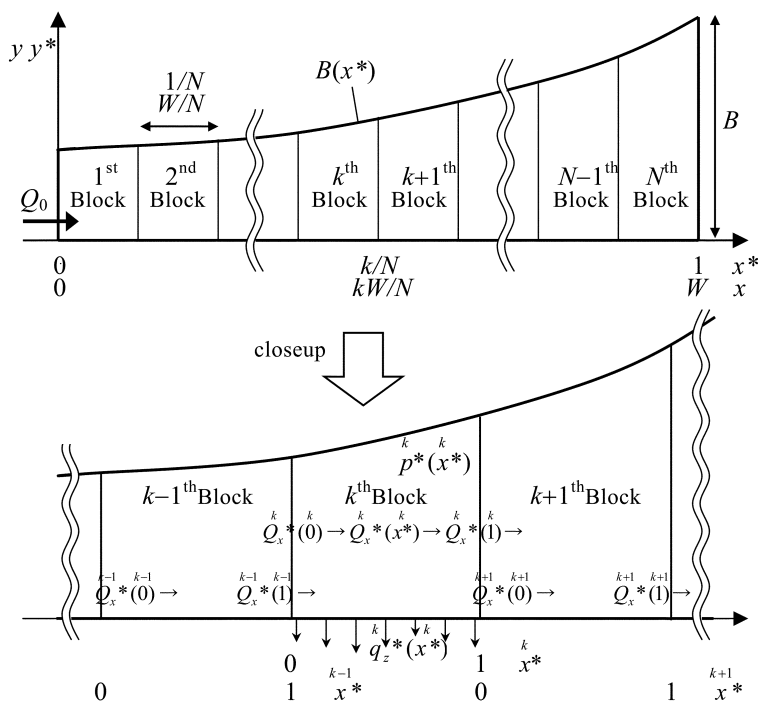

Fig. 2. Schematic illustration of segmentalized die blocks model.

$$
Q_{x}^{k}\left(x^{*}\right)=Q_{x}^{k} \stackrel{k}{(1)}+\frac{k}{q_{z}} \frac{W}{N}(1-\stackrel{k}{*})
$$

\subsection{2 各内部流路の全体統一規格化}

各金型ブロック内の流れは式(3), (7) と同様の方程式によっ て与えられる。 それぞれを前報の手順を応用して解くことに より ${ }^{18)}$ 各金型ブロック内での流量の規格化式が分配室内無 次元圧力 $\left.p^{*}{ }^{k} x^{*}\right)$ の関数として式(15), (16)のように表される.

$$
\stackrel{k}{Q}_{x}^{*}\left(\stackrel{k}{x^{*}}\right)=-\frac{1}{8} \frac{R}{W} p^{k}{ }^{* 1}(\stackrel{k}{x})-\frac{1}{3} N_{\mathrm{B}}-\frac{2}{3} N_{\mathrm{B}}^{4}\left(\frac{R}{W} \stackrel{k}{p^{*}}{ }^{k}(\stackrel{x}{*})\right)^{-3}
$$

$$
\begin{aligned}
& { }_{q_{z}}^{k}\left(x^{*}\right)=\frac{k}{q_{z}} *=\frac{1}{3} \frac{\stackrel{k}{B_{\mathrm{c}}}\left(x^{*}\right)^{3} W}{\pi L R^{3}} \\
& \left(2 \stackrel{k}{p^{*}} \stackrel{k}{\left.x^{*}\right)}-3\left(\frac{L}{B_{\mathrm{c}}\left(x^{*}\right)} N_{\mathrm{B}}\right)+\left(\frac{L}{B_{\mathrm{c}}\left(x^{*}\right)} N_{\mathrm{B}}\right)^{3} \stackrel{k}{p^{*}}\left(x^{*}\right)^{-2}\right)
\end{aligned}
$$

式(15)，(16)はそれぞれ $k$ 個の式を持つ有限集合である。こ の集合内での相互関係を保持するため，規格化の際に個々の 金型ブロックではなく，金型全体における統一条件で規格化 する.このとき, $\left.p^{*}{ }^{*} x^{*}\right)$ は以下のように表される.

$$
\stackrel{k}{p^{*}} \stackrel{k}{\left(x^{*}\right)}=\frac{R}{\mu_{0} \bar{v}_{0}} \stackrel{k}{p}\left(\stackrel{k}{x^{*}}\right)
$$

式(6-b)に用いられている平均流速は，各金型ブロック分配 室のそれぞれの入口座標 $x^{*}=0$ ではなく，金型全体の入口を示 す座標 $x^{*}=0$ (すなわち, 1 番目の金型ブロックの入口座標 $x^{*}=0$ ) における平均流速である。これは $N_{\mathrm{B}}$ についても同様であるた め，式(5)がそのまま成立する.

このとき，式(12)の各金型ブロック間の連続性は保持され るため, 各金型ブロック間の分配室内圧力の関係は以下のよ うに表される.

$$
\begin{array}{cl}
1 & 1 \\
p^{*}(0)=p^{*}(0), & p^{*}(1)=p^{*}(1), \\
k^{k+1}{ }^{k+1}{ }^{k} \stackrel{k}{ }(0)=p^{*}(1) & (1 \leq k \leq N-1)
\end{array}
$$

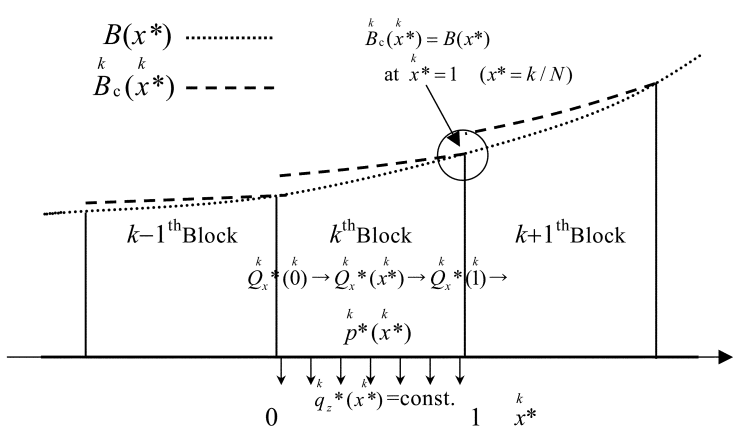

Fig. 3. Geometry approximation for each segmentalized die blocks. 
$\stackrel{k}{Q}_{x}^{*}\left(x^{k}\right)$ においても $Q_{x}^{*}\left(x^{*}\right)$ と同様, $Q_{0}=\pi R^{2} \bar{v}_{0}(=$ 全体金型への 投入流量）で規格化する， $Q_{0}$ は，それぞれの金型ブロックの 入口ではなく 1 番目の金型ブロック入口に流入する流量で ある。

$\stackrel{k}{Q}_{x}^{*}\left(x^{k}\right)$ に列いて同様に式(13)の連続性は保持されるため, 各金型ブロック間の関係は以下のように表される。このと き, $Q_{x}^{*}{ }^{*}\left(x^{*}\right)$ は各ブロックにおいてではなく, 金型全体において 1から0に変化する.

$$
\left.\stackrel{1}{Q}_{x}^{*}(\stackrel{1}{0})=1 \quad \stackrel{N}{Q_{x}} * \stackrel{N}{1}\right)=0,
$$$$
Q_{x}^{k+1} *\left(\begin{array}{l}
k+1 \\
0
\end{array}\right)=\stackrel{k}{Q_{x}^{k}} \stackrel{k}{(1)} \quad(1 \leq k \leq N-1)
$$

$\left.{ }_{q_{z}^{k}}^{*}{ }^{k} x^{*}\right)$ についても $q_{\mathrm{z}}^{*}\left(x^{*}\right)$ と同様に, $\bar{q}_{\mathrm{z}}=Q_{0} / W=\pi R^{2} \bar{v}_{0} / W$ (金型全 体の平均スリット流量) で規格化する.ここで, 理想化され たスリット形状 $B_{\mathrm{c}}^{k}\left(x_{k}^{k}\right)$ を持つ各金型ブロックにおいて $q_{z}^{k}\left(x^{k}\right)$ は $x^{k}$ によらない一定值 $\frac{k}{q_{z}}$ をとるが, 各ブロックの平均スリット流 量で規格化されているわけではないため, 金型全体の平均ス リット流量と一致していなければ, $\frac{k}{q_{z}^{*}}=1$ は成立しない.

これらのことから, 式(14)も同様に以下のように規格化さ れる。

$$
\stackrel{k}{Q}_{x}^{*}(\stackrel{k}{x} *)=\stackrel{k}{Q_{x}} *(\stackrel{k}{1})+\frac{k}{q_{z}} * \frac{1-\stackrel{k}{x^{*}}}{N}
$$

この式(14-b)を式(15)に代入して解けば, $p^{k_{*}^{*}}\left(x^{k}\right)$ が式(17)のよ うに求められる.ただし, $s^{k}\left(x^{*}\right),{ }^{k} u\left(x^{k}\right)$ は以下のとおりである.こ れらの式において $N=1$ とおいた場合に, 前報の結果と一致す る. ${ }^{18)}$

$$
\begin{aligned}
& \stackrel{k}{p^{* \prime}}\left(\stackrel{k}{x^{*}}\right)=\frac{2}{3} \frac{W}{R} N_{\mathrm{B}} \cdot \stackrel{k}{s}\left(\stackrel{k}{x^{*}}\right) \\
& \left(1+\left(1+u^{k}\left(x^{*}\right)\right)^{\frac{1}{2}}+\sqrt{2-u^{k}\left(x^{*}\right)+2\left(1+u^{k}\left(x^{*}\right)\right)^{-\frac{1}{2}}}\right) \\
& \stackrel{k}{k}\left(x^{*}\right)=1+\frac{3}{N_{\mathrm{B}}}\left(Q_{x}^{k} * \stackrel{k}{(1)}+\frac{k}{q_{z}} * \frac{1-x^{*}}{N}\right) \\
& \stackrel{k}{u^{k}}\left(x^{*}\right)=\frac{3}{2} s^{k}\left(x^{k}\right)^{-2} \\
& \left(\left(\begin{array}{l}
k{ }^{k} \\
\left.S^{*} x^{*}\right)^{2}+\sqrt{k^{k}\left(x^{*}\right)^{4}-1}
\end{array}\right)^{-\frac{1}{3}}+\left(\begin{array}{ll}
k k^{k} \\
S\left(x^{*}\right)^{2}+\sqrt{s^{k}\left(x^{*}\right)^{4}-1}
\end{array}\right)^{\frac{1}{3}}\right)
\end{aligned}
$$

${ }_{p}^{k_{*}}(1)$ が既知の場合, 式(17)を積分すれば $p^{k}{ }^{*}\left(x^{k}\right)$ が以下のよう に求められる.

なお, 式(17)の積分には数值解析を必要とするが, 被積分 関数が単調な関数によって代数的に与えられているため, 容 易に精度良く求められる。 $\left.p^{*}\left(\stackrel{k}{x^{*}}\right)=\stackrel{k}{p^{*}} \stackrel{k}{k}\right)-\int_{x^{*}}^{1} \stackrel{k}{p^{* \prime}}\left(\stackrel{k}{x^{*}}\right) d x^{*}$

${ }_{p}^{k^{*}}(1)$ については, ${ }^{k}{ }^{*}=1$ におけるスリット形状条件 ${ }_{\mathrm{c}}^{k}(\stackrel{k}{1})=B(k / N)$ を式(16)に代入して解くことにより, 式(21)のように求めるこ とができる，本式において $N=1$ とおいた場合に，前報の結果 と一致する. ${ }^{18)}$

$$
\begin{aligned}
& p^{k}{ }^{k}(1)=\left(\frac{L}{B(k / N)} N_{\mathrm{B}}+\frac{k}{q_{z}} * \frac{\pi L R^{3}}{B(k / N)^{3} W}\right) \\
& \quad \times\left(\frac{1}{2}+\cos \left(\frac{1}{3} \arccos \left(1-2\left(1+\frac{\pi R^{3}}{B(k / N)^{2} W} \cdot \frac{\left.\frac{k}{q_{z}}\right)^{-3}}{N_{\mathrm{B}}}\right)\right)\right)\right.
\end{aligned}
$$

\subsection{3 吐出偏差の算出手順}

ここで以下の計算プロセスを実行する処理PQC (引数 : $p^{k}(1)$, $\stackrel{k}{k}_{x}^{*}(1)$, 戻り值 : $\left.{ }^{k-1}{ }^{*}(1),{ }^{k-1} Q_{x}^{*}(1), \frac{k}{q^{*}}\right)$ を定義する.

この処理は, 内部にあらかじめ与えた $B\left(x^{*}\right)$ の情報と, 式(14-b), (16)，(17)，(20)等を用いることで， $k$ 番目の金型ブロックの分 配室出口における圧力および流量の情報から，一つ上流の $k-1$ 番目の金型ブロックの分配室出口圧力および流量を算出 $し$, 同時に $k$ 番目のブロックの平均スリット規格化流量 $\frac{k}{q_{z}^{*}}$ 算出する. その処理の手順をFig.4に示す.

以下にPQCを用いた吐出分布計算のフローを示す（Fig.5に フローチャートを示す).

最初に，金型全体における分配室終端部を含む $N$ 番目の金 型ブロックにおいて, $\frac{N}{q_{z}^{*}}=1$ が成立すると仮定する. $x^{*}=1$ にお いて $B_{\mathrm{c}}(1)=B$ が成立するから，これらを式(21)に代入すれば,

\begin{tabular}{|c|c|c|c|}
\hline Step & Argument & Return value & Formula No. \\
\hline 1 & $\begin{array}{ll}k & k \\
p *(1), & B_{\mathrm{c}}(1)\end{array}$ & $\frac{k}{q_{z}} *$ & (16) \\
\hline 2 & $\frac{k}{q_{z}} *, \quad Q_{x}^{k} *(1)$ & $\begin{array}{c}Q_{Q^{k}}^{k}\left(x^{k} *\right) \\
\left(Q_{x}^{k}\left({ }^{k}\right)\right)\end{array}$ & $(14-b)$ \\
\hline 3 & $Q_{x}^{k} *\left(x^{k}\right)$ & ${ }^{k}{ }^{* \prime}\left(x^{*}\right)$ & (17), (18), (19) \\
\hline 4 & $\begin{array}{ll}k & k \\
p^{* \prime}\left(x^{*}\right), & k \\
p^{*}(1)\end{array}$ & $\begin{array}{l}k \\
p *(0)\end{array}$ & $(20)$ \\
\hline 5 & $\begin{array}{l}k \\
p^{*}(0)\end{array}$ & $\stackrel{k-1}{p} *(1)$ & $(12-b)$ \\
\hline 6 & $Q_{x}^{k} *\left(\begin{array}{l}k \\
0\end{array}\right)$ & $\stackrel{k}{k-1}_{Q_{x}^{*}}^{k-1}(1)$ & $(13-b)$ \\
\hline
\end{tabular}
分配室内圧力に関する初期条件 $p^{*}(1)$ が得られる. 分配室内流 量に関する初期条件 ${ }_{x}^{N}{ }^{*}(1)=0$ は明らかである.

処理PQCを $k=N$ から 1 まで繰り返すことで, 本来定義されて いない, $p^{*}(1), \stackrel{0}{Q}_{x}^{*}(1)$ が出現するが, これらについては以下の ように定義する.

$$
\stackrel{0}{p^{*}} \stackrel{0}{(1)}=\stackrel{1}{p^{*}} \stackrel{1}{(0)}, \quad \stackrel{0}{Q_{x}} *\left(\stackrel{0}{1)}=\stackrel{1}{Q_{x}} * \stackrel{1}{0}\right)
$$

このようにして得られた $Q_{x}^{*}(1)$ は，金型全体からみると投

Fig. 4. Arguments and return values in PQC processing. 
入流量 $Q_{0}$ と同じ意味であるが, 初期条件 $p^{*}(1)$ を求める際に用

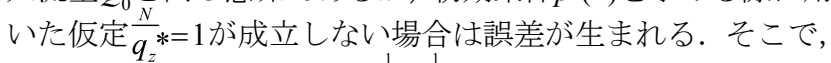
流量の誤差を表す比 $\varepsilon$ を $\varepsilon=Q_{x}^{*}(0) / Q_{0}$ と定義し, 最初に用いた $\bar{q}_{z}^{*}(=1)$ と $1 / \mathcal{E}$ の積を新たに $\frac{N}{q_{z}}{ }^{*}$ とおいて再度計算する. これを誤 差 $\left.\right|_{\varepsilon}-1 \mid$ が $1 / N$ 以下に収束导るまで繰り返す.このとき, PQC が算出した各金型ブロックにおける平均スリット規格化流

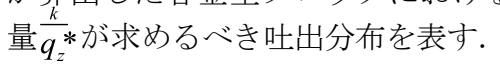

本計算の精度は必要な吐出偏差の精度に対応して, 金型ブ ロック数 $N に よ り$ 設定可能である. 現状のスリット形状 $B\left(x^{*}\right)$ に対する加工精度比は高々 $10^{-3}$ 程度であるので, $N=10^{3}$ にと れば充分である。

\section{4. 解析結果, 実験結果および考察}

\section{1 モデル材料の設定}

本報では，前報 ${ }^{18)}$ と同一のモデル材料を使用した. すなわ ち, ビンガム流体モデル用の試料 1 は, ナイロン粒子（粒径 $4.1 \mu \mathrm{m}$, 密度 $1.02 \times 10^{3} \mathrm{~kg} / \mathrm{m}^{3}$, 東レ製) をシリコーンオイル （TSF451-100，GE東芝シリコーン製）に濃度 $20 \mathrm{wt} \%$ で均一に 分散して調整したもので, $\mu_{0}=2.75 \times 10^{-1} \mathrm{~Pa} \bullet \mathrm{s}, \tau_{0}=18.0 \mathrm{~Pa}\left(25^{\circ} \mathrm{C}\right)$ である。

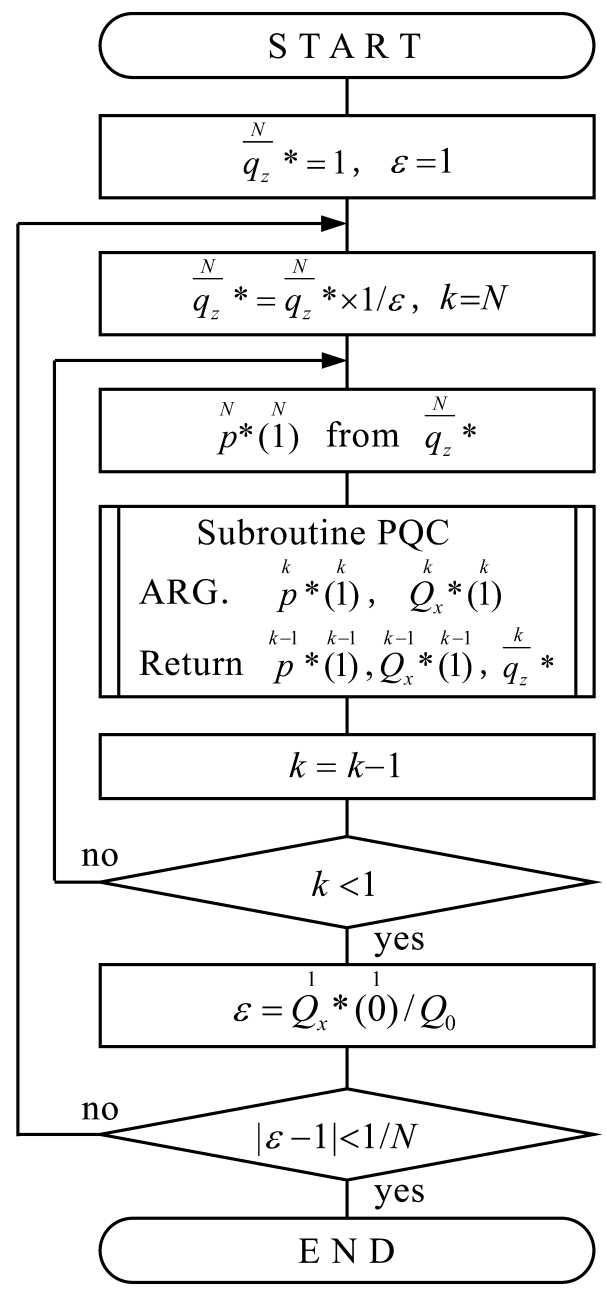

Fig. 5. Flowchart of the inductive calculation using PQC processing.
また, 比較のためのニュートン流体モデル用の試料 2 は, シ リコーンオイル2種を混合し粘度調整したもの（混合比： TSF451-100(65.5 wt\%), TSF451-1000(34.5 wt\%)) で, $\mu_{0}=2.74 \times 10^{-1} \mathrm{~Pa} \cdot \mathrm{s}\left(25^{\circ} \mathrm{C}\right)$ である.

物性の測定にはAnton Paar 社の応力制御型レオメータ (Physica MCR301) を使用した。

\section{2 システムの設定}

解析結果の検証用に使用した押出し金型塗布システムは, 主に, 液貯蔵部, 送液動力部および押出し金型部から成る. 送液動力部に関しては，液の降伏応力を無視できる充分な吐 出圧が確保できる容積式ポンプを使用した.

押出し金型の内部流路寸法は $W=0.140 \mathrm{~m}, R=3.06 \times 10^{-3} \mathrm{~m}$, $L=20.0 \times 10^{-3} \mathrm{~m}, B=0.15 \times 10^{-3} \mathrm{~m}$ である. 金型のスリット長 $L\left(x^{*}\right)$ は常に一定值 $L$ とている.

さらに，スリット出口に $x$ 方向に等距離で分割された液回 収部を設ける。

吐出量分布の測定は，押出し金型より一定吐出後，各分割 部の液量を重量法により測定し, 各分割部の吐出偏差=(各分 割部重量/平均重量) -1 によって表す.

また流量に関しては $Q_{0}=5.85 \times 10^{-7} \mathrm{~m}^{3} / \mathrm{s}$ を標準条件とし, 試料 1 を金型に投入する場合， $N_{\mathrm{B}}=10.0$ となる。実験においては, $N_{\mathrm{B}}=0$ の場合のみ試料2（ニュートン流体）を使用した。 その 他の $N_{\mathrm{B}}$ については, 試料 1 の投入流量 $Q_{0}$ を変化させることで 調整した.

\section{3 解析結果と実験結果との比較および考察}

\subsection{1 スリット形状が変化しない場合の吐出偏差}

Fig.6に試料1，2に対し，スリット形状が変化しない $\left(B\left(x^{*}\right)=B\right)$ 単純な内部流路形状の金型を使用した場合の吐出偏差の解 析結果と実験結果を示す.

いずれの試料においても，解析結果と実験結果の間には良 い一致が見られる.

ビンガム数 $N_{\mathrm{B}}$ が大きくなるほど, 分配室終端に近づくほど 降伏応力の影響を受けて流動抵抗が大きくなることで，ス リットへの流出量が減り, 吐出偏差が大きくなることが確認 できる.

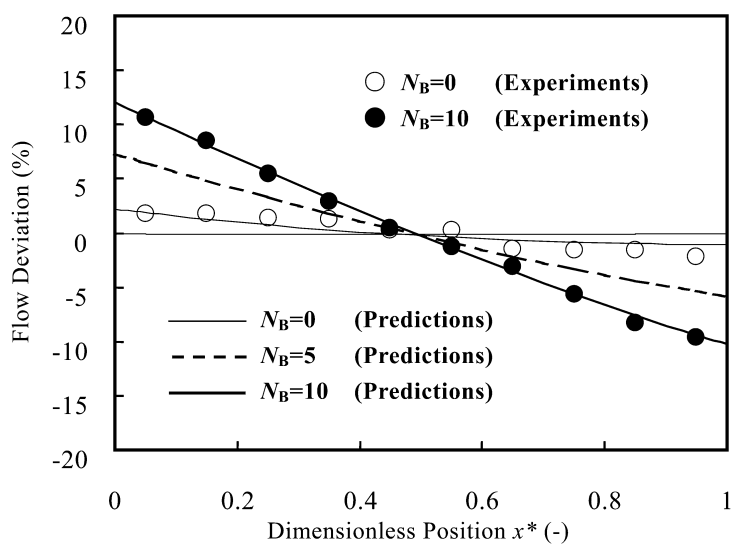

Fig. 6. Widthwise flow uniformity in a die having constant slit geometry. 


\subsection{2 理想的なスリット形状と近似直線}

Fig.7に吐出偏差がゼロになる条件で解析にて算出した理 想的なスリット形状 $B\left(x^{*}\right)$ を示す. これは本報において $N=1$ と おくことで計算でき，前報の算出式と一致する. Fig.7から， $N_{\mathrm{B}}$ の值が大きいほどスリット形状を大きく変化させる必要 があることがわかる。

ここで， $B\left(x^{*}\right)$ を $x^{*}=0$ において $B(0), x^{*}=1$ において $B(1)=B$ を 通る直線を $B_{\mathrm{AP}}\left(x^{*}\right)$ とし, $B_{\mathrm{AP}}\left(x^{*}\right)$ でスリット形状を近似した押 出し金型を考える. Fig. 8 に $B_{\mathrm{AP}}\left(x^{*}\right)$ の $B\left(x^{*}\right)$ に対する偏差 $\left(B_{\mathrm{AP}}\left(x^{*}\right)-B\left(x^{*}\right)\right) / B\left(x^{*}\right)$ を示す.

Fig.8から理想的なスリット形状は $N_{\mathrm{B}}$ のある領域で直線に 近くなる傾向があることがわかる（この金型においては $N_{\mathrm{B}}=15$ 付近). ただし, ここに示した条件の範囲では, 直線近 似したスリット形状の理想的な形状からの偏差は，最大でも 加工精度の誤差程度である。

本来, 理想的なスリット形状は $N_{\mathrm{B}}$ のみの関数でなく, 流路 設定条件 $(W, R, L, B)$ の関数でもあるが，一般的な内部流 路形状を持つ押出し金型においては， $N_{\mathrm{B}}$ がある程度大きいと き理想的なスリット形状が直線的となる傾向が見られること が多い（金型の形状は対象とする製品によって大きく異なる ため，ここでは紹介しないが本手法によって計算できる).

そこで理想的なスリット形状の代わりに，直線近似したス リット形状 $B_{\mathrm{AP}}\left(x^{*}\right)$ を持つ金型を考える. この金型を使用した

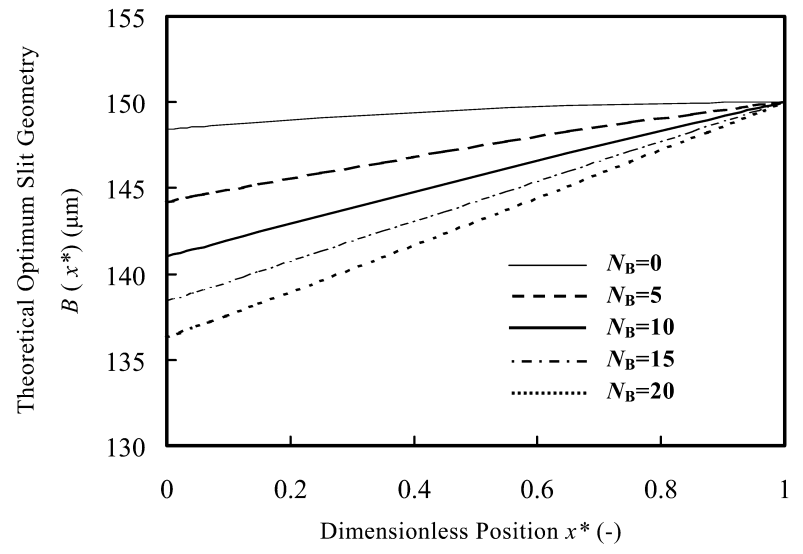

Fig. 7. Theoretical predictions of the optimum slit geometry.

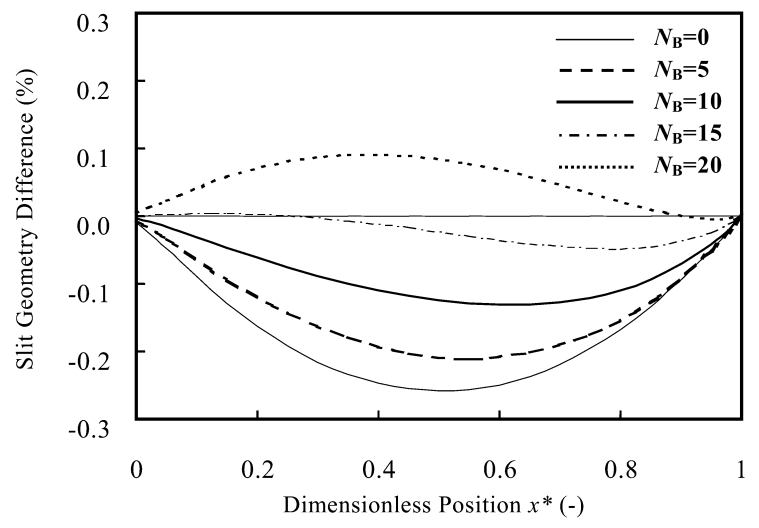

Fig. 8. Difference between optimum geometry and approximation.
場合の吐出偏差の解析結果をFig.9に示す。この結果によれ ば，その偏差は一般的な工業製品において許容される誤差の 範囲（塗布される製品の塗布膜厚偏差の要求仕様に依存す る）をおよそ満足している。つまり，金型内部流路設計にお けるこのような近似手法がビンガム流体に対して有効であ るといえる。

\subsection{3 任意のスリット形状における吐出偏差の予測}

次に, 金型に対して塗布条件が変化した場合について述べる.

Fig. 10 は $N_{\mathrm{B}}=10.0$ における理想的な形状に対して直線近似 したスリット形状 $B_{\mathrm{AP}}\left(x^{*}\right)$ を持つ押出し金型に, $N_{\mathrm{B}}$ が異なる条 件において吐出させた場合（流量を変化させたり，物性の異 なる液を使用する場合）を示したものである.

ここにおいて， $N_{\mathrm{B}}$ の変化は投入流量を標準条件に対し $1 / 2$ 倍，2倍に変えることにより行っている．これは一つの金型 を用いて $N_{\mathrm{B}}$ を変化させた例であるが，理想的なスリットの形 状はそれぞれの $N_{\mathrm{B}}$ によって異なるため，Fig.10の結果は理想 的でない任意のスリット形状を持った金型に対する吐出偏 差予測の実証結果と捉えることができる．これについても解 析結果と良い一致が見られる。

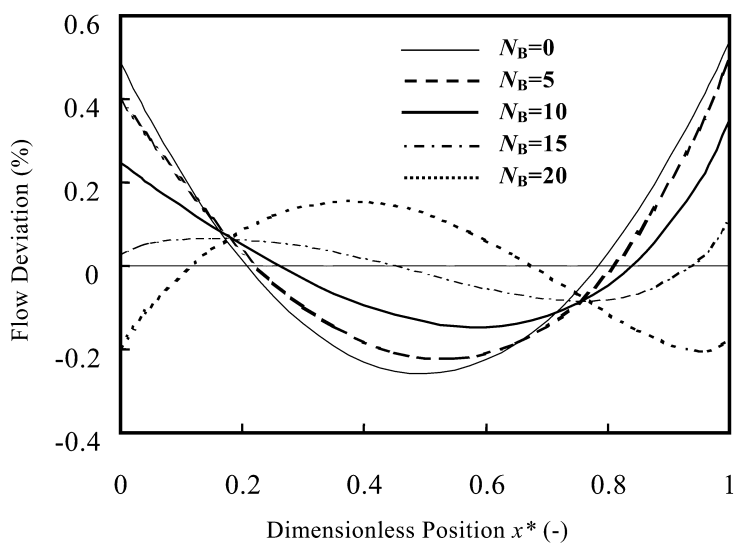

Fig. 9. Widthwise flow uniformity in the approximated optimum slit geometry.

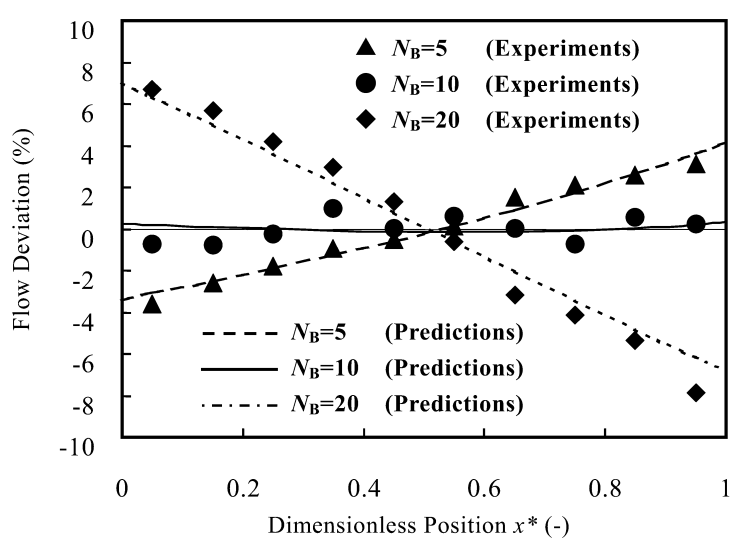

Fig. 10. Widthwise flow uniformity in the approximated optimum slit geometry designed for the flow condition of which Bingham number is 10 . 
慣性力が小さい範囲において，ニュートン流体の場合は塗 布液の物性や投入流量の変化による吐出偏差の変化はない ため ${ }^{8)}$, 塗布液の変更や生産速度の変更に対して金型の形状 変更は必要ないが, ビンガム流体の場合は変更が必要になる 場合がある。しかし，同じ金型を用いる場合においては吐出 偏差は $N_{\mathrm{B}}$ のみの関数であるため, 調整が可能な場合もある (例えば降伏応力が 1.8 倍, 粘度が1.2倍の塗布液を使用する場 合は，投入流量を 1.5 倍にすればよい)。もとより塗布条件の 変更によって生まれる誤差が製品の許容範囲に入っていれ ば，金型は形状変更せずにそのまま使用できる. 本解析手法 はそれを判断する上でも有効であることがわかる.

\section{5. 結 論}

本報においては，塗布時に用いられる押出し金型の任意の スリット形状を，理想化された曲線で与えられたスリット形 状を有する多数の微小幅金型ブロックの集合と見なすこと によって，ビンガム流体の塗布時に生じる吐出偏差を精度良 く効率的に予測できる解析手法を提案した。 また, 計算結果 と実験值の比較を行い，本解析手法の有効性を確認した。

さらに, 吐出偏差を許容範囲内に抑えるためのスリットの 形状の評価方法と, 加工の負荷を極小化するスリット形状近 似手法，さらには塗布条件の設定方法について紹介した.

ここでは工業的な加工負荷が少ない単一の直線による近 似の例のみを示しているが，本解析手法はビンガム流体を使 用する場合において，任意のスリット形状に対して適用可能 である.したがって, 製品に付加される価值が金型加工の負 荷に見合うのであれば, 必要とされる吐出偏差や液の物性条 件, 金型の流路設定条件に応じて, スリット形状を複数の直 線や曲線で近似して流路を設計してもよい。逆に，既存の金 型に対して吐出偏差を最小にできる生産条件（流量条件）や 塗布液の物性についても, 本解析手法に従って算出できる.

今後は，一般的に使用される塗布液によく見られる，降伏 応力の影響と同時にシェア・シニングの影響も受ける流体等 に対しても適応可能な解析手法を検討寸る予定である.

\section{REFERENCES}

1) Spasojević D, Irvine TF, Afgan N, International Journal of Multiphase Flow, 1, 607 (1974).

2) Yano S, Otsuka K, Kawai A, Hagiwara T, Sawaguchi T, Nihon Reoroji Gakkaishi (J Soc Rheol, Jpn), 33, 23 (2005).

3) Narumi T, See H, Oumi Y, Satou F, Hasegawa T, Nihon Reoroji Gakkaishi (J Soc Rheol, Jpn), 33, 29 (2005).

4) Tsuda T, Hasegawa T, Narumi T, Journal of the Japan Society of Mechanical Engineers Series B, 67, 2174 (2001).

5) Iida Y, Coating Gijutsu, 37 (1999), Technical Information Institute Co., Ltd.

6) Kigasawa T, Nojo K, Coating, 157 (1999), Converting Technical Institute.

7) Durst F, Lange U, Raszillier H, Chemical Engineering Science, 49, 161 (1994).

8) Gutoff EB, Journal of Imaging Science Technology, 37, 615 (1993).

9) Smith DE, Wang Q, Polym Engng Sci, 45, 953 (2005).

10) Wang Y, Polym Engng Sci, 31, 204 (1991).

11) Lee KY, Liu TJ, Polym Engng Sci, 29, 1066 (1989).

12) Lee KY, Wen SH, Liu TJ, Polym Engng Sci, 30, 1220 (1990).

13) Weinstein SJ, Ruschak KJ, AIChE Journal, 42, 1501 (1996).

14) Weinstein SJ, Ruschak KJ, AIChE Journal, 42, 2401 (1996).

15) Yuan SL, Polym Engng Sci, 35, 577 (1995).

16) Kamişli F, International Journal of Engineering Science, 41, 1059 (2003).

17) Tsuda $T$, Hasegawa $T$, Narumi $T$, Nihon Reoroji Gakkaishi (J Soc Rheol, Jpn), 30, 133 (2002).

18) Nagashima $M$, Hasegawa $T$, Narumi $T$, Nihon Reoroji Gakkaishi (J Soc Rheol, Jpn), 34, 91 (2006).

19) Leonard WK, Polym Engng Sci, 25, 570 (1985).

20) Tomita Y, “Rheology”, 316 (1975), Corona Publishing Co., Ltd. 